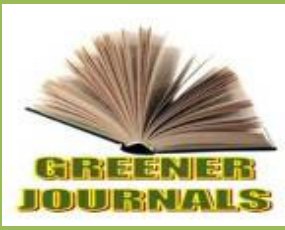

\title{
Breeding Practices and Strategies for Genetic Improvement of Indigenous Goats in Ethiopia: Review
}

\author{
Ahmed Seid
}

Jimma University, Department of Animal Science, Jimma, Ethiopia P.O. Box 307, Jimma.

\section{ARTICLE INFO}

Article No.: 051817064

DOI: 10.15580/GJAS.2017.4.051817064

Submitted: 18/05/2017

Accepted: 24/05/2017

Published: 05/06/2017

${ }^{*}$ Corresponding Author

Ahmed Seid

E-mail: seidahmad5@gmail.com

Phone: +251936917755

Keywords:

Breeding objectives, Breeding

strategies, selection criteria
This review was aimed to summarize and synthesize the fragmented information on breeding objectives, breeding practice of goat keeper's and effectiveness of existing goat cross breeding program as an input for suitable and sustainable genetic improvement strategies. Goats in Ethiopia are found in all agro-ecological zones. However, the selection criteria, breeding objectives and breeding practices of goat keepers are not similar across all agro ecologies and production systems. In arid and semi-arid lowlands of the country, the primary breeding objective of most of goat keepers was milk yield while in highland parts of the country goat owners keep goats for income generation to be used for different purposes like emergency cases and different household expenses. Cross breeding of goats as productivity improvement program had been implemented for nearly twenty seven years in the country via different projects. However, the result indicated that, in comparison to indigenous breeds, the crossbreds were not productive under village conditions where over $\mathbf{8 3 . 9} \%$ of Ethiopian human population is found. The reasons for fruitless ending of some of the projects were lack of clear targets aligned to the production environments, incompatibility of the genotype with the farmers breeding objectives, management methods and absence of involvement of all stakeholders in the productivity enhancement program. Therefore, there needs to be a concerted effort to formulate and implement suitable and sustainable breeding program. Community- based breeding program on the adapted indigenous breeds seems to be undoubted to increase and sustain the productivity of goats in the countryso as to meet the demands of the ever growing human population. 


\section{INTRODUCTION}

Small ruminants make a substantial contribution to the well being of the people in east Africa and Sub-Saharan Africa (De Leeuw and Rey, 1995). Goats are amongst the commonest farm animal species which sustain the livelihoods of smallholder farmers, pastoralists and agropastoralists (Workneh and Peacock, 1993). According to CSA (2016) there are about 29.70 million goats in Ethiopia, of which about 71.57 percent are females and 28.43 percent are males.

In Ethiopia, goats are one of the most important livestock species with eight genetically diverse breeds (Tesfaye, 2004).With respect to their originality, almost all of the goats are indigenous/native breeds, which account about $99.96 \%$ (CSA, 2016). They become adapted to a range of environments from the arid lowlands (the pastoral and agro-pastoral production system) to the humid highlands (mixed farming systems) (Workneh, 1992, ESGPIP, 2008).In these different production systems, goats provide their owners with a vast range of products and services such as meat, milk, skin, hair, horns, bones, manure, security, gifts, religious rituals and medicine. They are also important protein sources in the diets of the poor and help to provide extra income and support (Notter, 2012).

Goat production is one of the low resource demanded and efficient farming types, since goats have broad feeding habit, adaptation to unfavorable environmental conditions, low cost of maintenance, inherent suitability for small scale production and their short reproductive cycle. These provide goats with comparative advantage over cattle and sheep to suit the circumstances of especially resource poor livestock keepers (Alemayehu, 1993; Silanikove, 2000; Misra and Singh, 2002; Degen, 2007). Their presence in mixed species grazing systems can lead to a more efficient use of the natural resource and add flexibility to the management of livestock (ESGPIP, 2008). They also have the reputation of being resistant to the majority of tropical diseases and parasites than chicken and other animals.

The present production levels of indigenous goats with existing breeding strategies and practice are far below their potential. Productivity per animal is reported to be very low and contributes only $16.8 \%$ of the total ruminant livestock meat output.The annual meat production is estimated at $3-3.5 \mathrm{~kg}$ per animal per year in the population and 8-10 kg per animal slaughtered. These values are very low when compared with those in neighboring countries that have goat population, $50-75 \%$ less than Ethiopia. The average carcass weight of Ethiopian goats is $10 \mathrm{~kg}$, which is the second lowest in sub-Saharan Africa (Amha, 2008).

Even though other factors like slaughtering goats at immature body weight, mostly before castration, and low input production, contributes for low meat yield (FAO, 2008), the cross breeding program designed and implemented via different goat productivity improvement projects not ended as expected especially under farmer's goat production environment (Gebremeskel, 2000; Ayalew et al., 2003). Identifying those traits that farmers would like to improveis the first step to be made in designing genetic improvement strategies (Hammond and Galal, 2000). While previous studies have identified breeding objectives of goat owners, criteria's for selection of breeding buck and doe, and general breeding practices associated with the rearing of indigenous goats in different production systems of Ethiopia (Alemayehu, 1993; Nigatu, 1994; Endeshaw, 2007; Belete, 2009; Tesfaye, 2009; Grum, 2010; Tesfaye, 2010; Mahilet, 2012; Dhabaet al, 2013; Belete, 2013; Bruh, 2013; Alefe, 2014; Hulunim, 2014; Ahmed et al., 2015; Alubel, 2014; Tsigabu, 2015; Feki and Berhanu, 2016; Zergaw et al., 2016) organized information is not available. Therefore, the objective of this review is to summarize and synthesize the fragmented information on breeding objective, breeding practice of goat keeper's and efficacy of existing goat cross breeding program as an input for suitable and sustainable genetic improvement strategies.

\section{Breeding Objectives of Ethiopian Goat Keepers}

Many of the potential animal breeding strategies refer to a broader definition of breeding objectives, not aiming at higher production levels per animal only, but balancing higher productivity with improved functional traits such as health, fertility, and feed intake capacity (Olesen et al., 2000).

Breeding objectiveis the first step to be made in designing genetic improvement strategies. The breeding objective identifies those traits that farmers would like to improve. To able to identify the traits, the existing and future development objective of the agricultural production in the country is to be defined and the livestock production system to be characterized. The current livestock population structure should be described and opportunities, to better utilize it and hence, maximize the realization of genetic gain, should be sought for and some appropriate changes should be made (Hammond and Galal, 2000). Payne and Hodges (1997) stated that breeding objectives should match the expectations and values of the community. Furthermore, each trait in the breeding goal is given a 'goal value', indicating the contribution of the improvement of the trait to the realization of the development objectives. Since the relative rate of improvement will be faster for traits which have higher heritabilities, emphases should be given to traits with acceptable heritability. As a general guideline, traits with heritabilities less than $10 \%$ are considered lowly heritable and one cannot realistically expect to make much genetic progress (Funk, 1992).

According to Mohammad and Raed (2009), the breeding objectives of goat keepers differ based on agro ecologies, herd size, housing type and culture of the 
communities. The primary breeding objectives of goat keepers in many parts of Ethiopia are producing marketable goats for generating income which is used for emergency cases, educational fees and for other household expenses (Tesfaye, 2009; Mahilet, 2012; Hulunm, 2014; Ahmed et al., 2015;Alubel, 2015; Tsigabu, 2015; Zergaw et al., 2016) while milk production is the main breeding objectives in other parts of the country (Nigatu, 1994; Grum, 2010; Tesfaye, 2010; Belete, 2013; Alefe, 2014; Feki and Berhanu, 2016). In contrast, Endeshaw (2007) reported that, saving is the primary breeding objectives of goat keepers in Sidama Zone of south Ethiopia.

According to the previous studies (Nigatu, 1994; Endeshaw, 2007; Grum, 2010; Tesfaye, 2010; Mahilet, 2012; Belete, 2013; Alefe, 2014; Alubel, 2014; Hulunm, 2014;Tsigabu, 2015; Feki and Berhanu, 2016; Zergaw et al., 2016) goat keepers intended to have milk production as one of their breeding objectives are found in broad areas of the country (east Showa, west Arsi, Bale,MetaRobi, Borena, eastern Hararghe of Oromia regional state, Konso and Sidama zone of south Ethiopia, Shabelle and Siti zone of Somali national regional state, Bati, Kalu, Wag Hmira zone of Amhara region, Central Tigray zone of north Ethiopia, Gambella region of south western Ethiopia, Afar national regional state and Dire Dawa). Since goats browse different variety of trees and shrubs, goat owners believed that goat milk has medicinal value for children and contribute much more for the wellbeing of human baby (Grum, 2010; Tesfaye, 2010; Mahilet, 2012). However, according to Ahmed et al. (2015) in Horro Guduru Wollega zone of Oromia region, Alubel (2014) in north Gondar zone of Amhara region, Belete (2009) in Jimma zone of Oromia region and Tesfaye (2009) in Metema district of Amhara Region, goat milk is not consumed by the community and milk production is not the breeding objective of goat owners. The other commonly reported breeding objectives of goat keepers are meat for home consumption, ceremony (meat for holy days), sign of wealth \& strength and using by products (manure and skin) (Nigatu, 1994; Endeshaw, 2007; Grum, 2010; Tesfaye, 2010; Mahilet, 2012; Belete, 2013; Alefe, 2014; Alubel, 2014; Hulunm, 2014;Tsigabu, 2015; Feki and Berhanu, 2016; Zergaw et al., 2016).

\section{Breeding Practice of Goat Keepers in Ethiopia}

\section{Breeding bucks and does selection criteria}

Buck is the most important animal in the flock. It contributes $50 \%$ of the genetic makeup of kid born and determines overall pregnancy rate of the flock. The choice of good breeding buck is an important factor and fundamental in goat production. Accurate selection of does also raise the average productivity of the flock, however buck selection is the main driver of ongoing genetic improvement in the flock.

In different parts of Ethiopia goat owners understood the advantage of using superior bucks and developed their own breeding criteria to select the best performing buck (Table 1). As indicated by different authors, coat color type/pattern, body conformation, growth rate and Libido are important selection criteria of breeding buck (Mahilet, 2012; Alubel, 2014; Hulunm, 2014; Ahmed et al., 2015; Tsigabu, 2015; Zergaw et al., 2016). 
Table 1: Farmers selection criteria for breeding bucks and does

\begin{tabular}{|c|c|c|c|}
\hline Breeds/Goat types & $\begin{array}{l}\text { Major selection criteria/traits of } \\
\text { interest }\end{array}$ & $\begin{array}{l}\text { Production } \\
\text { system }\end{array}$ & Sources \\
\hline $\begin{array}{l}\text { Horro Guduru } \\
\text { Wollega goat types } \\
\text { (Western highland ) }\end{array}$ & $\begin{array}{l}\text { Doe: liter size, growth rate, age at first } \\
\text { Kidding, Appearance } \\
\text { Buck: growth rate, appearance, coat colour type }\end{array}$ & Mixed farming & Ahmed et al. 2015 \\
\hline $\begin{array}{l}\text { Hararghe Highland } \\
\text { Goat }\end{array}$ & $\begin{array}{l}\text { Doe:size / appearance, age at 1st sexual maturity, } \\
\text { twining ability and high milk yield } \\
\text { Buck: size / appearance, absence of horn and growth } \\
\text { rate, coat colour type }\end{array}$ & $\begin{array}{l}\text { Mixed crop- } \\
\text { livestock }\end{array}$ & Mahilet, 2012, \\
\hline Abergelle Goats & $\begin{array}{l}\text { Doe: Milk production, Twining ability, Body } \\
\text { Conformation, Frequent kidding } \\
\text { Buck: Coat color, Body conformation, Growth rate }\end{array}$ & $\begin{array}{l}\text { Mixed crop- } \\
\text { livestock }\end{array}$ & Alubel,2015 \\
\hline $\begin{array}{l}\text { Meanit and Sheko } \\
\text { (Keffa) } \\
\text { Goats }\end{array}$ & $\begin{array}{l}\text { Doe: Twinning ability, kid growth, } \\
\text { mothering ability and body size; } \\
\text { Buck: body size, pedigree and } \\
\text { growth rates }\end{array}$ & $\begin{array}{l}\text { Mixed crop- } \\
\text { livestock and } \\
\text { agropastoral }\end{array}$ & Tegegne, 2012 \\
\hline Arsi-Bale goats & $\begin{array}{l}\text { Doe: milk production, family } \\
\text { history, twinning ability, } \\
\text { mothering ability, kid growth rate, } \\
\text { coat colour and kidding interval; } \\
\text { Buck: coat colour, family } \\
\text { history, testicular characteristics, } \\
\text { libido, growth rate, prolificacy and } \\
\text { disposition/ character }\end{array}$ & $\begin{array}{l}\text { Mixed crop- } \\
\text { livestock }\end{array}$ & $\begin{array}{l}\text { Tesfaye et al. } \\
2012 b\end{array}$ \\
\hline Afar goats & $\begin{array}{l}\text { Family history (progeny of superior } \\
\text { sire and high milk producing doe), } \\
\text { large body size, conformation; coat } \\
\text { colour }\end{array}$ & $\begin{array}{l}\text { Pastoral and } \\
\text { agropastoral }\end{array}$ & Feki 2013. \\
\hline $\begin{array}{l}\text { Goat types in } \\
\text { Shabelle (Somalia) }\end{array}$ & $\begin{array}{l}\text { Buck:Appearance, growth rate and color } \\
\text { Doe:High milk yield, Kidding interval, Kid growth, Age at } \\
\text { sexual maturity, Size/Appearance }\end{array}$ & $\begin{array}{l}\text { Pastoral and } \\
\text { agropastoral }\end{array}$ & Alefe, 2014 \\
\hline $\begin{array}{l}\text { Gambella goats } \\
\text { (Western Low land) }\end{array}$ & $\begin{array}{l}\text { Doe:size/appearance, color and prolificacy } \\
\text { Buck: Size, color, horn availability }\end{array}$ & $\begin{array}{l}\text { Pastoral } \\
\text { Agropastora/ } \\
\text { Mixed farming }\end{array}$ & Tsigabu, 2015 \\
\hline
\end{tabular}

Like selection of bucks, goat keepers also practiced selection of breeding does and had different selection criteria. The selection criteria of farmers to identify the breeding doe were different according to agro ecology, production system and culture of the community. According to Mahilet (2012), size / appearance, age at $1^{\text {st }}$ sexual maturity, twining ability and high milk yield were considered as the first four reasons for doe selection in Harrerghe highland of Ethiopia. However, some authors (Belete; 2009; Ahmed et al., 2015; Alubel, 2015) reported that milk yield was not the selection criteria of goat owners to select their breeding does.

\section{Breeding bucks ownership and mating system}

Several studies have shown that most goat keepers inBati, Borena, Somali, Wag Hmira,Central Tigray, south Omo and East Gojjam have used their own breeding bucks to mate their breeding does (Biruh, 2013; Demissie et al., 2014; Alubel, 2014; Hulunm, 2014) while, in Horro Guduru Wollega, llu Abba Bora, Jimma and Arsi-Bale of Ethiopia, goat keepers used neighbors breeding buck to mate their breeding does (Belete, 2009; Tesfaye, 2010; Dhaba et al., 2013; Ahmed et al., 2015).
According to Ahmed et al. (2015), most goat keepers in Horro Guduru Wollega zone of Oromia region allowed does to be served by any buck when the does show signs of heat. Similarly, from goat keepers which have breeding buck, most of them allowed their bucks to mate does other than their own flock. The primary reason for this was bucks run with does throughout the year and the flock was mixed with neighboring household's flock during communal grazing and watering. According to Workneh and Rownalds (2004) in Oromia, Hulunm (2014) in Bati and kalu district of Amhara region, Dhaba et al., (2013) in llu Abba Bora zone of Oromia region, uncontrolled natural mating system had been practiced by goat keepers. Farther more, due to all goats grazed/browsed together in communal grazing land and housed together at night, farmers also allowed the breeding buck to mate his own mother, daughter and sister (Alubel, 2014; Ahmed et al., 2015). The advantage of natural uncontrolled mating is that it allows for all year round breeding (Kosgey, 2004). In contrary, uncontrolled mating together with small flock sizes and poor/absent record keeping on pedigree are expected to result in severe inbreeding which leads to poor growth rates (Saico and Abul, 2007). Goat keepers in some parts of Ethiopia did not practice special 
management for breeding bucks (Alubel, 2014; Hulunm, 2014; Ahmed et al., 2015).

\section{Culling as flock Management Tool and Reasons of culling from the flock}

Culling in goat flocks is an important tool for the development of a good flock. Culling should be stringent and used as a means of improving the genetic quality and productivity of a flock. Flock size can be maintained by replacing culled goats doelings in the flock (ESGPIP, 2008). Reasons of culling could be different for different production systems and agro-ecologies.

According to different authors (Belete, 2009; Belete, 2013; Dereje et al., 2013, Demissie et al., 2014; Ahmed et al., 2015) culling practiced by goat owners in Ethiopia. As indicated by Belete (2009), Dhaba et al., 2013 and Ahmed et al. (2015), goat owners in western part of Ethiopia cull their goats from the flock based on reproductive problem, old age, sickness, unwanted physical characteristics and physical defect. Productivity problems, disease, persistent poor body condition and synergetic effects of all these factors were the common top four reasons for destocking goat flock in west Hararghe, Eastern Ethiopia (Dereje et al., 2013). Demissie et al. (2014) also reported that health problem was the primary reason of the goat keepers for culling of their goats in East Gojjam Zone of Ethiopia.

Goat keepers in Bale zone of Oromia region culled their goats at average age of 8.17 years for males and 8.5 years for females (Belete, 2013). However, the report of Girma (2008) showed that from reproductive point of view, it is essential to intensively cull does after 5-6 years of age. Most goat owners used sealing and slaughtering as a means of culling unproductive goats and kids that did not fit the selection criteria of goat keepers.

\section{Cross Breeding for Goat Genetic Improvement in Ethiopia}

Production from the indigenous livestock under traditional management of subsistence farmers is generally considered too low, and hence crossbreeding and improved level of care should be promoted as a quick way of attaining higher production and productivity under private commercial farms as well as smallholder management in selected sites in the highlands with a conducive climate for intensification. This is the basis for the policy of the Ethiopian government on livestock development in general (Gebremeskel and Tedla, 1995).

In Ethiopia, crossing the existing genetic resource with exotic genetic blood levels were started around twenty seven years ago with main focus on improving milk production and growth rates (Teressa, 2004). Since then, cross breeding works of goats were implemented by non-governmental organizations like FARM Africa, Agri-service Ethiopia, and governmental organization like Ministry of Agriculture (MoA), higher learning institutions, research institutions and agricultural development offices as part of the Ethiopian Sheep and Goat Productivity and Improvement Program (ESGPIP) with USAID funding (Solomon et al., 2014).

In eastern part of the country, indigenous goats were crossed with Anglo-Nubian goats with the help of FARM-Africa dairy goat development project (Gebremeskel, 2000). There were also different crossbreeding projects at Werer (Afar and Saanen) and Holetta (highland and saanen) research centers by Institute of Agricultural Research (Aschalew et al., 2000). Research on Arsi-Bale and Boran goats at the Adami Tulu Research Center was also the longest-running project on goats in Ethiopia, running for more than 15 years from 1992 (Solomon et al., 2014).

However, most of the implemented projects lacked functional institutional synergies and exit strategies. In comparison to indigenous breeds, the crossbreds were not profitable, under village conditions where over $83.9 \%$ (CSA, 2007) of Ethiopian population is found especially, when returns per unit live weight or metabolic weight were taken into account (Workneh, 2000). Moreover, the adoption rates of crossbred genotypes by farmers were found to be very low, in some cases as low as $20 \%$ with most of the adopters being better-off households rather than poor farmers (Teressa, 2004). The reasons for unsuccessful ending of some of the projects were lack of clear targets aligned to the production environments and farmers breeding objectives. Cross breed goats from Werer research centers, could not adapt arid and semi-arid agroecologies. On the other hand, since Holetta is a cool highland where goats are not an important livestock species, focusing on goat development was ill-conceived (Solomon et al., 2014).In general, many small ruminant cross breeding programs in tropical country were not successful because of the incompatibility of the genotype with the farmers breeding objectives, management methods, absence of involvement of all stakeholders in the designing of breeding strategies and the prevailing environment of the tropical low input production systems ((Rischkowsky, 1996; Ayalew et al., 2003; Wollny, 2003; Kosgey et al., 2006).

Although there has been some effort by international organizations along with the national institutions to improve production and productivity of goats in Ethiopia, there needs to be a concerted effort to formulate and implement suitable and sustainable breeding program and strategy for goat production in view of its importance to the national economy. Selective pure breeding of the adapted indigenous breeds seems to be essential to increase and sustain the productivity of goats in the countryso as to meet the demands of the human population.

\section{CONCLUSION}

The review reveals that the selection criteria, breeding objectives and breeding practices of goat keepers varied based on agro ecology and culture of the community. In 
arid and semi-arid lowlands of the country, the primary breeding objective of goat keepers was milk yield while in highland parts of the country goat owners keep goats for income generation to be used for different purposes. This indicates that when designing breeding program, such differences should be considered. In addition, uncontrolled mating together with small flock sizes and poor/absent record keeping on pedigree especially in highlands of Ethiopia may direct to severe inbreeding which leads to poor growth rates. Therefore, goat keepers should take training about importance of buck exchange and controlled mating.

The performance of indigenous breeds were appreciable than crossbred goats particularly under village conditions. Therefore, community- based selective breeding program of the adapted indigenous breeds seems to be undoubted to increase and sustain the productivity of goats in the countryso as to meet the demands of the ever growing human population. For evolving possible selection and breeding strategies for goat production in Ethiopia, one should have to keep in mind the various agro-climatic and socio-economic aspects along with the production constraints, as they have an important bearing on the overall success of such programs.

\section{ACKNOWLEDGEMENTS}

The Author greatly acknowledges Jimma University for all support. Special thanks to my beloved wife Sihen Getachew for her numerous supports in all stages of this work.

\section{REFERENCES}

Ahmed S, Kefelegne K, Kefena E.2015. Breeding Objective, Selection Criteria and Breeding Practice of Indigenous Goats in Western Ethiopia: Implications for Sustainable Genetic Improvement. Greener Journal of Agricultural Sciences. 5(5): 167176, http://doi.org/10.15580/GJAS.2015.5.072715105.

Alefe Takele.2014.Phenotypic Characterization of Indigenous Goat Types and Their Production System in Shabelle Zone, South Eastern Ethiopia Msc Thesis Presented To Haramaya University. Dire Dawa, Ethiopia.

Alemayehu Reda .1993. Phenotypic characterization of indigenous goats and goat husbandry practices in East and South East Ethiopia. An M.Sc Thesis presented to Alemaya University, Alemaya, Ethiopia. pp. 135 .

Alubel Alemu.2015.On-Farm Phenotypic Characterization and PerformanceEvaluation of Abergelle and Central Highland GoatBreeds As An Input for Designing Community-BasedBreeding
Program Msc Thesis presented to Haramaya University. Dire Dawa, Ethiopia.

Amha Sebsibe.2008. Sheep and Goat Meat Characteristics and Quality. Goat Production Handbook for Ethiopia.60-79pp.

Aschalew Tsegahun, Sisay Lemma, Ameha Sebsbie, Abebe Mekoya and Zinash Sileshi. 2000. National goat research strategy in Ethiopia. In: Markel, R.C., Abebe, G. and Goetsch, A.L. (eds), The opportunities and challenges of enhancing goat production in East Africa: Proceeding of a conference held at Awassa, Debub University. pp. $1-5$.

Belete Shenkute .2009. Production and Marketing Systems of Small Ruminants in Goma District of Jimma Zone, Western Ethiopia. M. Sc. Thesis presented to Hawassa University, Ethiopia.

Biruh Tesfahun.2013. Phenotypic and production system characterization of Woyto Guji Goats in Lowland areas of South Omo Zone. An MSc thesis submitted to School of Animal and Range Science, School of Graduate Studies Haramaya University. 89pp.

CSA.2016. Federal Democratic Republic of Ethiopia, Central Statistical Agency (CSA) Agricultural sample survey,Volume II, report on livestock and livestock characteristics (private peasant holdings). Statistical bulletin,570, April 2013, Addis Ababa, Ethiopia.

Degen A .2007. Sheep and goat milk in pastoral society. Small Ruminant Research 68, 7-19.

DeLeeuw PN and Rey B .1995. Analysis of current trends in the distribution patterns of ruminant livestock in tropical Africa. World Animal Review. 83: 47-59.

Dhaba Urgessa, Belay Duguma, Solomon Demeke and Taye Tolamariam.2013. Breeding Practices and Reproductive Performance of Traditionally Managed Indigenous Sheep and Goat in Ilu Abba Bora Zone of Oromia Regional State, Ethiopia. Global Veterinaria 10 (6): 676-680, 2013.

Endeshaw Assefa.200. Assessment of Production and Marketing System of Goats in Dale District, Sidama Zone M.Sc Thesis University of Hawassa, Ethiopia

ESGPIP.2008. Genetic improvement of sheep and goat. Ethiopia Sheep and Goat Productivity Improvement Program. Sheep and goat production handbook for Ethiopia. Addis Ababa, Ethiopia pp. 99-101.

Feki Misbah \& Berhanu Belay.2016. Livelihood and Socio-Cultural Significance of Afar Goat Breed Intended For Breed Improvement Programs. Journal of Agricultural Science and Research (JASR) Vol. 3, Issue 2, 2016, 13-22

Grum Gebreyesus.2010. Community-Based Participatory Characterization of the short Eared Somali Goat Population around Dire Dawa. An MSc thesis submitted to School of Animal and Range Science, School of Graduate Studies Haramaya University. 129pp.

Hulunim Gatew.2014.On-Farm Phenotypic Characterization and Performance Evaluation of 
Bati, Borena and Short Eared Somali Goat Populations of Ethiopia.An M.Sc. Thesis presented to Haramaya University. Dire Dawa, Ethiopia.

M.J. Tabbaa and R. Al-Atiyat.2009.Breeding objectives, selection criteria and factors influencing them for goat breeds in Jordan. Small Ruminant Research 84 (2009) 8-15

Mahilet Dawit.2012. Characterization of Hararghe Highland Goat and Their Production System in Eastern Hararghe. An M.Sc. Thesis presented to Haramaya University. Dire Dawa, Ethiopia.

Misra A K and Singh K.2002. Effect of water deprivation on dry matter intake, nutrient utilization and metabolic water production in goats under semi-arid zone of India. Small Ruminant Research 46, 159165.

Nigatu Alemayehu.1994. Characterization of Indigenous Goat Types \& husbandry Practices in Northern Ethiopia. An M.Sc.Thesis presented to Alemaya University of Agriculture. Alemaya, Ethiopia.pp86

Nottor D R .2012. Genetic Improvement of reproductive efficiency of sheep and goat. Animal Reproduction Science 130:147-151

Silanikove N.2000. The physiological basis of adaptation in goats to harsh environments. Small Ruminant Research 35, 181-193.

Solomon, A.K., Mwai, O., Grum, G., Haile, A., Rischkowsky, B.A., Solomon, G. and Dessie, T. 2014. Review of goat research and development projects in Ethiopia. ILRI Project Report. Nairobi, Kenya: International Livestock Research Institute.

Tefera Gebremeskel. 2000. The experience of FarmAfrica in a goat development project in Ethiopia. In: Markel, R.C., Abebe, G. and Goetsch, A.L. (eds), The opportunities and challenges of enhancing goat production in East Africa: Proceeding of a conference held at Awassa, Debub University. pp. 107-112.

Teressa Adugna. 2004. Factors influencing adoption of cross bred dairy goats. The case of three districts in eastern Ethiopia. In: Asfaw Yimegnuhal and Tamirat Degefa (eds), Proceedings of the 11th annual conference of the EthiopianSociety of Animal Production (ESAP) held in Addis Ababa, Ethiopia, 28-30 August 2004. Addis Ababa, Ethiopia: ESAP. p.332.

Tesfaye Alemu.2004. Genetic characterization of indigenous goat population of Ethiopia using microsatellite DNA markers. A Thesis submitted to the National Dairy Research Institute (Deemed University) Karnal (Haryana), India.258pp.
Tesfaye Alemu.2004. Genetic characterization of indigenous goat populations of Ethiopia using Microsatellite DNA markers. National Dairy Research Institute, Deemed University, Haryana, India. (Ph.D. thesis).

Tesfaye Kebede. 2009. Assessment of genetic and phenotypic parameters for reproductive and survival traits in indigenous Arsi-Bale goats. MSc thesis. Dire Dawa, Ethiopia: Haramaya University.

Tsigabu Gebreselassie.2015. Phenotypic Characterization of Goat Type and Their Husbandry Practices in Nuer Zone of Gambella People Regional State, South Western Ethiopia. An M.Sc. Thesis presented to Haramaya University. Dire Dawa, Ethiopia.

Wollny C.B.A.2003. The need to conserve farm animal genetic resources in Africa: should policy makers be concerned? Ecol. Econ 45: 341-351.

Workneh A.1992. Preliminary survey of indigenous goat types and goat husbandry practices in Southern Ethiopia. An M.Sc. Thesis presented to Alemaya University of Agriculture. Alemaya, Ethiopia.

Workneh, A. 2000. Do smallholder farmers benefit more from crossbred (Somali $\times$ Anglo Nubian) than from indigenous goats? PhD thesis. Goettingen, Germany: Faculty of Agricultural Sciences, George August University of Goettingen.

Workneh, A. and Peacock, C.P. 1993. The goat as an important milk producer in Southern Ethiopia. In: Proceedings of the fourth National Livestock Improvement Conference, 13-15 November 1991, Addis Ababa, Ethiopia. Addis Ababa,Ethiopia: IAR (Institute of Agricultural Research). pp. 165-170.

Workneh, A., Getahun, E., Tibbo, M., Mamo, Y. and Rege, J.E.O. 2003. Current state of knowledge on characterization of farm animal genetic resources in Ethiopia. Farm animal biodiversity in Ethiopia: Status and prospects. In: AsfawYimegnuhal and Tamrat Degefa (eds), Proceedings of the 11th annual conference of the Ethiopian Society of AnimalProduction (ESAP) held in Addis Ababa, Ethiopia, 28-30 August 2003. Addis Ababa, Ethiopia: ESAP. p. 441.

Zergaw N, Dessie T and Kebede K 2016:Indigenous breeding practices and selection criteria of goat owners in Konso and Meta-Robi districts, Ethiopia: implications for designing community based breeding strategy. Livestock Research for Rural Development. Volume 28, Article \#133. Retrieved October 22, 2016, from http://www.Irrd.org//rrd28/7/zerg28133.html 